\title{
Loss of redundant gene expression after polyploidization in plants
}

F. García-Olmedo, P. Carbonero, C. Aragoncillo and G. Salcedo

Departamento de Bioquimica, E. T. S. Ingenieros Agrónomos, Madrid-3 (Spain), 1 August 1977

Summary. Based on chromosomal location data of genes encoding 28 biochemical systems in allohexaploid wheat, Triticum aestivum L. (genomes AABBDD), it is concluded that the proportions of systems controlled by triplicate, duplicate, and single loci are $57 \%, 25 \%$, and $18 \%$ respectively.

Ferris and Whitt ${ }^{1}$ have recently presented compelling evidence of an extensive loss of duplicate gene expression after polyploidization in Catostomidae fish: $35 \%-50 \%$ of duplicate genes expressed in the most advanced tetraploid catostomids and $55 \%-65 \%$ in the most primitive species. They have also summarized the previous findings concerning this aspect of polyploid evolution in fish. We report here this type of calculation for allohexaploid wheat, Triticum aestivum $\mathrm{L}$. (genomes AABBDD), a member of the well-known plant polyploid complex AegilopsTriticum.

The loss of redundant gene expression in wheat was realized quite early. Riley ${ }^{2}$ postulated the diploid-like status of some systems in tetraploid wheat on the basis of indirect evidence. Some of as ${ }^{3,4}$ surveyed the distribution of genetic variants of 2 biochemical systems (genes for sterol esterification and the purothionins) in 22 species of the Aegilops-Triticum group and concluded that redundant genetic activity had been lost in $25 \%$ and $50 \%$ of the cases, respectively. All the observed losses seemed to occur in a non-random fashion, affecting the additional genomes and not the so-called pivotal ones.

The development by Sears ${ }^{5,6}$ of the compensated nullitetrasomic series and other aneuploids of the T. aestivum $c v$. Chinese Spring has permitted several groups, including ours, to investigate the chromosomal location of genes that control different biochemical systems. These data, which are summarized in the table, permit not only the estimation of the percentage of gene triplication and duplication expressed, but also to discern where the pre- 
sumed 'losses of redundancy', or inactivations, have taken place. Out of 28 sets of homoeologous systems, $16(57 \%)$ are controlled by triplicate loci, $7(25 \%)$ by duplicate loci, and $5(18 \%)$ by single loci. In Catostomidae fish', the proportion of silenced loci per genome ranged from $18 \%$, in the most primitive species, to $37 \%$, in the most advanced ones. In hexaploid wheat, the proportions silenced in each genome are $\mathrm{A}(32 \%)>\mathrm{B}(18 \%)>\mathrm{D}(11 \%)$. The $\mathbf{A}$ and $\mathbf{B}$ genomes have coexisted in tetraploid wheat for some time before the more recent addition of the $D$ genome to form the hexaploid, so the higher proportion of silenced loci in the A and B genomes, as compared with the $\mathrm{D}$ genome, could reflect the longer time they have been undergoing diploidization. However, the estimated figures for silenced loci in the wheat genomes must be considered quite high, as compared with those calculated for the catostomids, if the much longer evolutionary history of the latter ( 50 million versus 10,000 years) is taken into account. The number of triplicate genes expressed in wheat could be underestimated if those sets in which the 3 genes encode proteins with the same electrophoretic mobility were overlooked. However, this is unlikely, because such systems are also detected using aneuploids, on the basis of gene dosage responses, and their frequency seems to be low in an alloploid like wheat.

Chromosomal location of genes that control biochemical systems in allohexaploid wheat, Triticum aestivum (genomes AABBDD]

\begin{tabular}{|c|c|c|c|}
\hline System & Chromosomes & No. of loci & Ref. \\
\hline $\begin{array}{l}\text { Acp } \\
\text { Adh } \\
\text { a-Amy }\end{array}$ & $\begin{array}{l}4 A, 4 B, 4 D \\
4 A, 4 B, 4 D \\
6 A, 6 B, 6 D \\
7 A, 7 B, 7 D\end{array}$ & $\begin{array}{l}3+3 \\
3 \\
3\end{array}$ & $\begin{array}{l}7 \\
8 \\
9\end{array}$ \\
\hline Apep & $6 A, 6 B, 6 D$ & 3 & 10 \\
\hline Epep & $7 \mathrm{~A}, 7 \mathrm{~B}, 7 \mathrm{D}$ & 3 & 11 \\
\hline Est & $\begin{array}{l}3 A, 3 B, 3 D \\
6 A, 6 B, 6 D \\
7 A, 7 B, 7 D\end{array}$ & $\begin{array}{l}3 \\
3 \\
3\end{array}$ & $\begin{array}{l}12,13 \\
13 \\
12\end{array}$ \\
\hline Got & $\begin{array}{l}3 A, 3 B, 3 D \\
6 A, 6 B, 6 D\end{array}$ & $3+3$ & 14 \\
\hline Lpx & $\begin{array}{l}4 A, 4 B, 4 D \\
5 A, 5 B, 5 D\end{array}$ & $\begin{array}{l}3 \\
3\end{array}$ & 11 \\
\hline $\begin{array}{l}\text { Pth } \\
\beta \text {-Amy }\end{array}$ & $\begin{array}{l}1 \mathrm{~A}, 1 \mathrm{~B}, 1 \mathrm{D} \\
4 \mathrm{~A},-4 \mathrm{D}\end{array}$ & $\begin{array}{l}3 \\
2\end{array}$ & $\begin{array}{l}15 \\
16\end{array}$ \\
\hline $\mathrm{Px}$ & $-, 1 B, I D$ & 2 & 13 \\
\hline $\begin{array}{l}\text { Glut-sub } \\
\text { CM1, } 2\end{array}$ & $\begin{array}{l}-, 1 \mathrm{~B}, 1 \mathrm{D} \\
-, 7 \mathrm{~B}, 7 \mathrm{D}\end{array}$ & $\begin{array}{l}2 \\
2\end{array}$ & $\begin{array}{l}17 \\
18\end{array}$ \\
\hline NGE 16,17 & $4 A,-, 4 D$ & 2 & 19,20 \\
\hline NGE 12,13 & $4 A,-, 4 D$ & 2 & 19,20 \\
\hline $\begin{array}{l}\text { NGE 5,7 } \\
\text { Glut-sub }\end{array}$ & $\begin{array}{l}-3 \mathrm{~B}, 3 \mathrm{D} \\
=-4 \mathrm{D}\end{array}$ & 2 & $\begin{array}{l}19,20 \\
17\end{array}$ \\
\hline NGE 11 &,$--7 \mathrm{D}$ & 1 & 19,20 \\
\hline NGE 2 & $-, 6 B,-$ & $\mathbf{1}$ & 19,20 \\
\hline NGE Jo & $-, 6 B,-$ & 1 & 19,20 \\
\hline NGE 14 & $-, \mathbf{3 B},-$ & $\mathbf{1}$ & 19,20 \\
\hline
\end{tabular}

-Acid phosphatase (Acp); Alcohol dehydrogenase-NAD (Adh); $\alpha$-Amylase ( $\alpha$-Amy); Aminopeptidase (Apep) ; Endopeptidase (Epep); Esterases (Est); Glutamate oxalacetate transaminase (Got); Lipoxidase (Lpx); Purothionins (Pth); $\beta$-Amylase $(\beta$-Amy); Peroxidase (Px); Glutenin subunits (Glut-sub); Chloroform ; methanol proteins 1 and 2 (CMI, 2); Non-gliadin $70 \%$ ethanol extracted proteins (NGE), homoeologies of NGE proteins are based on their characterization by aminoacid analysis, MW determination, solubility properties, etc. $\{19,20$ and our unpublished results $\}$. Genes encoding gtiadins, located in chromosomes of groups 1 and 6 (Wrigley and Shepherdin) have not been included in oux calculations because in this system there are presumably tandem duplications.
One aspect of the data that might be significant, in the above context, is the fact that most of the presumably silenced loci are associated with endosperm proteins with no apparent enzymatic function, while most of the enzymatic loci are triplicated. This could indicate that some types of homoelogous sets are more constrained than others with respect to the loss of redundancy and that a greater fraction of the genomes would have to be investigated to get a reliable estimation. However, there are some arguments that could explain the high degree of gene silencing in wheat:

1. A more rapid gene loss could take place in the early history of the polyploid. As Ferris and Whitt ${ }^{1}$ have pointed out, the process does not seem to be entirely at random. 2. An alloploid is in fact a 'permanent heterozygote' in which positive and negative heterotic interactions between homoeoalleles are effectively fixed. Negative heterosis can thus be considered as a driving force for the loss of duplicate gene expression. This effect would be initially more important in an alloploid (wheat) than in an autoploid (fish) for obvious reasons. 3 . The disruption of the dosage balance between functionally related genes, implied in the loss of redundancy, has to be considered generally deleterious, and thus would tend to counteract whatever factors favor the loss. The disruption would be less drastic if the effective gene dosage is reduced by $1 / 3$ in a hexaploid (wheat) than by $1 / 2$ in a tetraploid (fish). Finally, available data on DNA content of hexaploid wheat and its ancestors $^{22}$, seem to indicate that, as in the case of fish ${ }^{1}$, there is no apparent DNA loss matching the loss of redundant gene expression.

1 S. D. Ferris and G. S. Whitt, Nature 265, 258 (1977)

2 R. Riley, in: Crop Plant Evolution, p. 103. Ed. J. Hutchinson. Cambridge University Press 1965.

3 F. Garcia-Olmedo, Nature 220, 1144 (1968).

4 P. Carbonero and F, Garcia.Olmedo, Experientia 25, 1110 (1969).

5 E. R. Sears, The aneuploids of common wheat. Mo. Agr. exp. Res. Bull. 572, 1 (1954).

6 E. R. Sears, in : Chromosome Manipulations and Plant Genetics, p. 29. Ed. R. Riley and K. R. Lewis. Oliver and Boyd, London 1966.

7 G. E. Hart, Genetics 74, 110 (abstr.) (1973).

8 G. E. Hart, Proc. nat. Acad. Sci. USA 66, 1136 (1970).

9 K. Nishikawa and M. Nobuhara, Jap. J. Genet. 46, 345 (1971).

10 G. E. Hart, Proc. 4th Int. Wheat Genet. Symp., p. 805. Ed. E. R. Sears and L. M. S. Sears, Columbia Mo. 1973.

11 G. E. Hart and P. Langston, Isozyme Bul1. 8, 12 (1975).

12 J. W. Bergman and N. D. Williams, Agron. Abstr. p. 23 (1972).

13 C. E. May, R. S. Vickery and C. J. Driscoll, Proc. 4th Int. Wheat Genet. Symp., p. 843. Ed. E. R. Sears and L. M. S. Sears. Columbia Mo. 1973.

14 G. E. Hart, Isozymes 3, 637 \{1975).

15 R. Fernández de Caleya, C. Hernández-Lucas, P. Carbonero and F. García-Olmedo, Genetics 83, 687 (1976).

16 P. Joudrier and Y. Cauderon, C. r. Acad. Sci. Paris 282, 115 (1976).

17 J. A. Bietz, K. W. Shepherd and J. S. Wall, Cereal Chem. 52, 513 (1975).

18 F. Garcla-Olmedo and P. Carbonero, Phytochemistry 9, 1495 (1970).

19 M. A. Rodriguez-Loperena, C. Aragoncillo, P. Carbonero and F. Garcia-Olmedo, Phytochemistry 74,1219 \{1975\}.

20 C. Aragoncillo, M. A. Rodriguez-Loperena, P. Carbonero and F. Garcia-Olmedo, Theor. appl. Genet. 45, 322 (1975).

21 C. W. Wrigley and K. W. Shepherd, Ann. N. Y. Acad. Sci. 209, 154 (1973).

22 A. H. Sparrow and A. F. Nauman, in: Basic Mechanisms in Plant Morphogenesis, p. 367. Brookhaven Symposia in Biology No 251973. 